Eurasscience Journals

Eurasian Journal of Forest Science (2015) 3(1): 1 - 13

\title{
EFFECTS OF SEASONAL CHANGES ON MICROBIAL BIOMASS AND RESPIRATION OF FOREST FLOOR AND TOPSOIL UNDER BORNMULLERIAN FIR STAND
}

\author{
İlyas BOLAT ${ }^{1 *}$, Ömer KARA ${ }^{2}$, Metin TUNAY ${ }^{3}$ \\ ${ }^{1 *}$ Bartın University, Faculty of Forestry, Department of Forest Engineering, Division of Soil Science and \\ Ecology, email: ilyasbolat@bartin.edu.tr, Bartın, Turkey. \\ ${ }^{2}$ Karadeniz Technical University, Faculty of Forestry, Department of Forest Engineering, \\ Division of Watershed Management, Trabzon, Turkey. \\ ${ }^{3}$ Bartın University, Faculty of Forestry, Department of Forest Engineering, Division of Forest \\ Construction and Transportation, Bartın, Turkey
}

\begin{abstract}
A significant parameter that links plants to soil is microbial biomass. Therefore, measurement of the biologically-active fractions of the soil organic matter, such as microbial biomass $\mathrm{C}, \mathrm{N}$ and $\mathrm{P}$, is a good way to quantify the quality of the soil. In this study, the seasonal dynamics of microbial biomass $\mathrm{C}, \mathrm{N}$ and $\mathrm{P}$ and associated microbial properties were investigated in the forest floor (litter, fermentation and humus) and topsoil $(0-5 \mathrm{~cm})$ under a stand of Bornmullerian fir (Abies nordmanniana subsp. bornmuilleriana Mattf.). According to One-Way ANOVA, the study showed that seasonal changes have a significant effect on the quantities of microbial biomass $\mathrm{C}, \mathrm{N}$ and $\mathrm{P}$ and associated microbial properties in the forest floor and soil. According to our study, the greatest amounts of microbial biomass $\mathrm{C}, \mathrm{N}$ and $\mathrm{P}$ in the forest floor and topsoil occurred during summer. Also, it can be said that seasonal variations have significant effects on microbial biomass $\mathrm{C}, \mathrm{N}$ and $\mathrm{P}$ in the forest floor and soil because they alter the climate and chemical characteristics of the soil. Annual releases of $\mathrm{C}, \mathrm{N}$ and $\mathrm{P}$ through microbial biomass were found higher in the forest floor than in soil. The results of this study indicated that variations in the microbial biomass and basal respiration during the different seasons are related to microbial activity changes.
\end{abstract}

Keywords: Basal respiration, biochemical properties, $\mathrm{C}_{\text {mic }}: \mathrm{C}_{\text {org }}$ percentage, $\mathrm{C}_{\text {mic }}: \mathrm{P}_{\text {mic }}$ ratio, metabolic quotient $\left(\mathrm{qCO}_{2}\right)$

Özet

Toprak ile bitki arasında bağlantı kuran en önemli parametre mikrobiyal biyokütledir. Bu nedenle, mikrobiyal biyokütle $\mathrm{C}, \mathrm{N}$ ve $\mathrm{P}$ gibi toprak organik maddesinin biyolojik olarak aktif bölümlerinin ölçümü, toprak kalitesinin belirlenmesinde çok faydalı bir yoldur. Bu çalışmada, Uludağ Göknarı (Abies nordmanniana subsp. bornmülleriana Mattf.) meşceresi altındaki üst toprak $(0-5 \mathrm{~cm})$ ve ölü örtüdeki mikrobiyal biyokütle $\mathrm{C}, \mathrm{N}$ ve $\mathrm{P}$ ile diğer bazı mikrobiyal özelliklerin mevsimsel değişimi araştırlmıştır. Basit varyans analizi (One-Way ANOVA) sonuçlarına göre, mevsimsel değişim üst toprak ve ölü örtüye ait mikrobiyal biyokütle $\mathrm{C}, \mathrm{N}$ ve $\mathrm{P}$ ile diğer bazı mikrobiyal özellikler üzerinde önemli etkiye sahiptir. Bu çalışmaya göre, üst toprak ve ölü örtüde en yüksek mikrobiyal biyokütle $\mathrm{C}, \mathrm{N}$ ve $\mathrm{P}$ içeriği yaz mevsiminde elde edilmiştir. Ayrıca, mevsimsel farklılık toprağın kimyasal özelliklerini ve iklimi değiştirmesinden dolayı mikrobiyal biyokütle $\mathrm{C}, \mathrm{N}$ ve $\mathrm{P}$ içeriği üzerinde de önemli etkiye sahiptir. Mikrobiyal biyokütleden serbest kalan $\mathrm{C}, \mathrm{N}$ ve $\mathrm{P}$ miktarının ölü örtüde topraktan daha fazla olduğu tespit edilmiştir. Bu çalışmanın sonuçları farklı mevsimlerde mikrobiyal biyokütle ve bazal solunumdaki değişimlerin mikrobiyal faaliyetteki değişimlerden kaynaklandığını göstermektedir.

Anahtar kelimeler: Bazal solunum, biyokimyasal özellikler, $\mathrm{C}_{\text {mic }}: \mathrm{C}_{\text {org }}$ yüzdesi, $\mathrm{C}_{\text {mic }}: \mathrm{P}_{\text {mic }}$ oranı, metabolik katsayı $\left(\mathrm{qCO}_{2}\right)$ 


\section{INTRODUCTION}

Soil microorganisms contribute to the maintenance of soil health and quality by controlling processes, such as decomposition of animal-plant residues, biogeochemical cycles, formation of soil structure and its maintenance, and the fate of agrochemicals and pollutants applied to soil. In addition to their significant role in soil functioning, soil microorganisms are potentially useful indicators of soil health and quality. They respond to soil management in time scales that are relevant to land managers. For example, changes in microbial biomass or abundance of selected functional groups of microorganisms (e.g. mycorrhizal fungi) can be detected precisely and rapidly when compared to changes in soil organic matter content or other soil physical and chemical properties (Powlson and Jenkinson 1981; Powlson et al. 1987; Pankhurst et al. 1997). Microbial parameters are proposed as rapid and sensitive indicators for detecting changes in soils. Today, international programs for monitoring soil health and quality involve the measurement of several biochemical properties such as microbial biomass, basal respiration, microbial diversity, and soil enzymes (Sparling 1997; Nielsen and Winding 2002; Alvarez et al. 2009).

However, in spite of its importance, the quantity of data on biomass and activity of microorganisms is limited in the natural forest ecosystems of Turkey compared to other countries. Although there are some studies on the soil microbial biomass in different forest ecosystems (Joergensen et al. 1995a 1995b; Mahia et al. 2006; Kara et al. 2008; Kara and Bolat 2008a; Alvarez et al. 2009), the knowledge of seasonal changes in the microbial biomass and basal respiration in forest ecosystems is limited (Maithani et al. 1996; Chen et al. 2003; Patel et al. 2010; Kara et al. 2014). The fact that seasonal changes affect the soil moisture, soil temperature, root activity and amount of organic matter give rise to fluctuations in the soil. Also, these fluctuations vary according to factors such as soil type, amount and type of vegetation, land use and management (Kramer and Green 2000; Chen et al. 2003).

This study had three aims: (1) to determine the contents of $\mathrm{C}, \mathrm{N}$ and $\mathrm{P}$ in forest floor and soil; (2) to determine the seasonal fluctuation in microbial biomass $(\mathrm{C}, \mathrm{N}$, and $\mathrm{P})$, basal respiration and microbial indices $\left(\mathrm{C}_{\text {mic }}: \mathrm{C}_{\text {org }}, \mathrm{C}_{\text {mic }}: \mathrm{N}_{\text {mic }}, \mathrm{N}_{\text {mic }}: \mathrm{N}_{\text {total }}, \mathrm{C}_{\text {mic }}: \mathrm{P}_{\text {mic }}\right)$ in forest floor and soil; and (3) to evaluate the influence of climate and soil properties on microbial biomass and basal respiration.

\section{MATERIALS AND METHODS}

\section{Study area}

The study was carried out between April2009 and January-2010 in the city of Artt-Bartın in Turkey, near the Western Black Sea region of Turkey

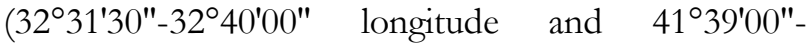
$41^{\circ} 42^{\prime} 00^{\prime \prime}$ latitude) with an average altitude of $830 \mathrm{~m}$ (ranging from 750 to $910 \mathrm{~m}$ ). The climate in the study area is very humid, mesothermal, and characterized by warm summers. There are four distinct seasons, spring (March-May), summer (June-August), autumn (September-November), and winter (DecemberFebruary). According to climatological data from the past 31 years, the annual mean temperature in the Arrt-Bartin is $8.6{ }^{\circ} \mathrm{C}$. January and February are the coldest months with mean temperatures of $(-3.6){ }^{\circ} \mathrm{C}$ and $(-3.9){ }^{\circ} \mathrm{C}$, respectively. July and August are the hottest months with mean temperatures of $23.9{ }^{\circ} \mathrm{C}$ and $24.2{ }^{\circ} \mathrm{C}$, respectively. The mean annual precipitation is $1431.4 \mathrm{~mm}$, round $16.78 \%$ (175.2 $\mathrm{mm})$ of which in spring, $21.36 \%(223.1 \mathrm{~mm})$ in summer, $31.78 \%(331.8 \mathrm{~mm})$ in autumn, and $30.06 \%$ (313.9 mm) in winter. The study area is dominated by Abies nordmanniana subsp. bornmülleriana. The surface area of stand is roughly $31 \mathrm{ha}$. The canopy closure of stand is between $70-100 \%$, approximately mean $85 \%$ which account for 378 trees per hectare, 30.68 basal area $\mathrm{m}^{-2} \mathrm{ha}^{-1}$ and 315.7 fortune (or volume) $\mathrm{m}^{-3} \mathrm{ha}^{-1}$. The stand within its boundaries has approximately the same properties. Also, there are infrequently Fagus orientalis, Carpinus betulus, Sorbus torminalis, Buxus sempervirens, Ilex colcbica and Arbutus unedo in the study area (TGDF 2001). Under the Bornmullerian fir stand, there is a moder humus form $(3-6 \mathrm{~cm})$. Parent material of the study area is limestone which is calcareous, stony and fine texture.

\section{Sampling of soil and forest floor materials}

Topsoil $(0-5 \mathrm{~cm})$ and forest floor material (litter, fermentation and humus) samples for both microbial and physical-chemical analysis were taken 
systematically from 15 different sites in Bornmullerian fir stand (in spring, summer, autumn and winter seasons). In each season, 30-forest floor and soil samples (totally 120) were taken from under the Bornmullerian fir stand. In addition to, all the abovementioned samples were included in duplicate. Stones, plant and root debris were removed before passing the soil samples through $2 \mathrm{~mm}$ sieves. Samples were stored at $4{ }^{\circ} \mathrm{C}$ until the measurement of microbial biomass $\mathrm{C}, \mathrm{N}, \mathrm{P}$ and basal respiration. Other subsamples of soil at a depth of $0-5 \mathrm{~cm}$ were collected from topsoil by soil cores (9.1 diameter), air-dried, ground and sieved $(<2 \mathrm{~mm})$ for physical and chemical analysis. Forest floor materials were also collected from the same area and stored until analysis as soil samples. To determine $\mathrm{pH}$, organic $\mathrm{C}$, total $\mathrm{N}$ and available $\mathrm{P}$, forest floor material was oven-dried at $70{ }^{\circ} \mathrm{C}$ until constant weight. Forest floor materials were then ground and sieved $(<1 \mathrm{~mm})$.

\section{Physical and chemical properties of soil and forest floor materials}

The moisture content of soil and forest floor was determined gravimetrically. Soil samples were dried in an oven at $105^{\circ} \mathrm{C}$ while those taken from the forest floor were dried at $70^{\circ} \mathrm{C}$ until constant weight (Gülçur 1974; Karaöz 1992). The temperature of both soil and forest floor were measured in the field by temperature sensors inserted into $0-5 \mathrm{~cm}$ depth while the samples of the forest floor and soil were retrieving in each season. Determination of soil particle size distribution was done according to the hydrometer method (Bouyoucos 1962). The $\mathrm{pH}$ of soil $(1: 2.5 \mathrm{w} / \mathrm{v}$; soil: water suspension) and forest floor material (1:20 $\mathrm{w} / \mathrm{v}$; forest floor: water suspension) were measured by a pH meter (Rowell 1994). The organic C content of the forest floor material and soil was estimated using the potassium dichromate oxidation, and total $\mathrm{N}$ content was estimated using Kjeldahl digestion (Karaöz 1992; Rowell 1994). The measurement of plant available $\mathrm{P}$ in both forest floor material and soil was done according to the modified ammonium molybdate-ascorbic acid method. The absorbance of the blue color formed was read at $880 \mathrm{~nm}$ using a UV-vis spectrophotometer (UV-2450 Shimadzu) (Rowell 1994; Anderson and Ingram 1996; Kacar 1996).

eurasscience.com

\section{Biochemical properties of soil and forest floor materials}

Microbial biomass $\mathrm{C}, \mathrm{N}$ and $\mathrm{P}$ were determined by the chloroform fumigation extraction method (Brookes et al. 1985). Microbial biomass C $\left(\mathrm{C}_{\text {mic }}\right)$ was determined by modifying the Walkley Black method (Brookes et al. 1985; Vance et al. 1987a) and calculated by using the following equation (Vance et al. 1987a):

Microbial Biomass $C=K_{E C} X 2.64$

Where $\mathrm{K}_{\mathrm{EC}}$ refers to the difference in extractable organic $\mathrm{C}$ between the fumigated and unfumigated samples and 2.64 is the proportionality factor for biomass $\mathrm{C}$ released by fumigation extraction.

The method described by Brookes et al. (1985) and Anderson and Ingram (1996) was used for measurement of microbial biomass $\mathrm{N}\left(\mathrm{N}_{\text {mic }}\right)$ and calculated as follows:

Microbial Biomass $N=F_{N} / 0.54$

Where $\mathrm{F}_{\mathrm{N}}$ is the difference between $\mathrm{N}$ extracted from fumigated and unfumigated samples and 0.54 is the fraction of microbial biomass $\mathrm{N}$ released by fumigation extraction.

Microbial biomass $\mathrm{P}\left(\mathrm{P}_{\mathrm{mic}}\right)$ was determined according to the method of Olsen et al. (1954) and Brookes et al. (1982). Microbial biomass P was calculated as following the equation below:

Microbial Biomass $P=E_{P} / 0.40$

Where $E_{P}$ is the difference between $P$ extracted from fumigated and unfumigated samples and 0.40 is the fraction of soil biomass $\mathrm{P}$ extracted after $\mathrm{CHCl}_{3}$ fumigation.

Basal respiration was determined by sodium hydroxide $(\mathrm{NaOH})$ trap method (Alef 1995). The metabolic quotient $\left(\mathrm{qCO}_{2}\right)$ was calculated as the basal respiration rate $\left(\mathrm{mg} \mathrm{CO}_{2}-\mathrm{C} \mathrm{h}^{-1}\right) \mathrm{g}^{-1}$ of microbial biomass (Anderson and Domsch 1990; Anderson and Domsch 1993).

\section{Statistical analyses}

Simple variance analysis (One-Way ANOVA) was performed to determine the difference in the physical, chemical and biological properties of forest floor and soil among the seasons. Tukey's HSD and 
Tamhane's T2 tests were carried out to compare the mean value of physical-chemical properties and microbial $\mathrm{C}, \mathrm{N}, \mathrm{P}$, basal respiration and metabolic quotient of forest floor and soil among the seasons. A $95 \%$ confidence limit $(p<0.05)$ was selected to indicate differences among samples.

\section{RESULTS}

\section{Physical and chemical properties of soil and forest floor materials}

Differences and similarities in forest floor and soil properties according to the seasons under Bornmullerian fir stand were assessed for a variety of characteristics (Table 1). Moisture content of forest floor ranged from 65.48 to $187.06 \%$ and soil from 33.32 to $73.64 \%$. The highest $\mathrm{pH}$ value was obtained in the winter season for forest floor samples, while in the soil samples it was in the spring season. The $\mathrm{pH}$ values of forest floor samples showed statistically significant $(p=0.001<0.05)$ difference whereas the values of soil samples showed no significant $(p=$ $0.111>0.05)$ difference. The percentage of organic $C$, an important chemical property, ranged from 28.73 to $32.32 \%$ and 5.21 to $6.08 \%$ in the forest floor and in the soil samples, respectively. Decomposition ratio $\left(\mathrm{C}_{\text {org }} / \mathrm{N}_{\text {total }}\right)$ both in forest floor and soil was found 21.52 and 18.05, respectively in the spring as the highest values.

\section{Biochemical properties of soil and forest floor materials}

\footnotetext{
Microbial biomass $\mathrm{C}\left(\mathrm{C}_{\mathrm{mic}}\right), \mathrm{C}_{\mathrm{mic}}: \mathrm{C}_{\text {org }}$ percentage and $\mathrm{C}_{\text {mic }}: \mathrm{N}_{\text {mic }}$ ratio

The content of microbial biomass $\mathrm{C}$ in the forest floor ranged from 3300.30 (in winter) to $5737.50 \mu \mathrm{g} \mathrm{g}^{-1}$ (in summer) while in the soil samples it was between 713.81 (in spring) to $1345.20 \mu \mathrm{g} \mathrm{g}^{-1}$ (in autumn) therefore it is approximately 5 times higher in the forest floor than in soil. One-way ANOVA test showed that both in the forest floor and soil there are significant $(p=0.013$ and $0.001<0.05$, respectively) differences among the seasons (Figure 1). $\mathrm{C}_{\text {mic }}: \mathrm{C}_{\text {org }}$ percentages in this study ranged from 1.11 to $2.03 \%$ and 1.17 to $2.20 \%$ in forest floor materials and soil samples, respectively. There are statistically significant
}

( $p=0.037$ and $0.048<0.05$ for forest floor and soil, respectively) differences among the seasons (Table 2).

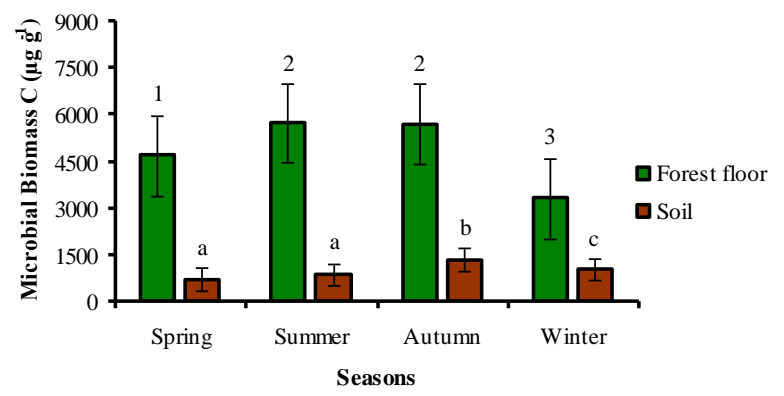

Figure 1. Seasonal changes in microbial biomass $\mathrm{C}$ content of forest floor and soil samples. Values shown by different number and lower case letter among the seasons are significantly different $(p$ $<0.05)$.

The ratio of $\mathrm{C}_{\text {mic }}: \mathrm{N}_{\text {mic }}$ obtained in the forest floor and soil varied between 6.63 to 8.48 and 4.45 to 6.65 , respectively. $\mathrm{C}_{\text {mic }}: \mathrm{N}_{\text {mic }}$ ratio in both forest floor and soil, which is frequently used as an indicator of the community of microbial biomass and microbial populations under stress due to $\mathrm{C}$ deficiency but abundance of N (Jenkinson and Ladd 1981; Dinesh et al. 2012), was higher in winter than in other seasons and there were statistically significant $(p=0.001$ and $0.007<0.05$ for forest floor and soil, respectively) differences among seasons (Table 2).

\section{Microbial biomass $\mathbf{N} \quad\left(\mathbf{N}_{\text {mic }}\right)$ and $\mathbf{N}_{\text {mic }}: \mathbf{N}_{\text {total }}$ percentage}

Maximum and minimum values of microbial biomass $\mathrm{N}$ varied seasonally between 392.63 to $881.03 \mu \mathrm{g} \mathrm{g}^{-1}$ in the forest floor and 149.51 to 223.63 $\mu \mathrm{g} \mathrm{g} \mathrm{g}^{-1}$ in the soil samples (Figure 2). The amount of microbial biomass $\mathrm{N}$ in forest floor was 2.5-4 times higher than in the soil and it peaked during autumn in both samples. Microbial biomass $\mathrm{N}$ differed significantly ( $p=0.000$ and $0.000<0.05$, respectively) by the season both in the forest floor and in the soil. $\mathrm{N}_{\text {mic }}: \mathrm{N}_{\text {total }}$ percentages of forest floor and soil were $2.28-5.28 \%$ and $4.28-6.33 \%$, respectively. $\mathrm{N}_{\text {mic }}: \mathrm{N}_{\text {total }}$ percentages differed significantly $(p=0.000$ and 0.000 $<0.05$, respectively) by the season both in the forest floor and in the soil. In both examples $\mathrm{N}_{\text {mic }}: \mathrm{N}_{\text {total }}$ percentages were higher in summer and autumn when compared to those in spring and winter (Table 2). 
Table 1. Changes in some physical and chemical properties of forest floor and soil among the seasons

\begin{tabular}{|c|c|c|c|c|c|c|c|c|}
\hline \multirow{3}{*}{$\begin{array}{c}\text { Physical and chemical properties of forest floor and } \\
\text { soil }\end{array}$} & \multicolumn{8}{|c|}{ Seasons and Samples Types } \\
\hline & \multicolumn{2}{|c|}{ Spring } & \multicolumn{2}{|c|}{ Summer } & \multicolumn{2}{|c|}{ Autumn } & \multicolumn{2}{|c|}{ Winter } \\
\hline & $\begin{array}{c}\text { F. } \\
\text { floor }\end{array}$ & Soil & $\begin{array}{c}\text { F. } \\
\text { floor }\end{array}$ & Soil & $\begin{array}{c}\text { F. } \\
\text { floor }\end{array}$ & Soil & $\begin{array}{c}\text { F. } \\
\text { floor }\end{array}$ & Soil \\
\hline Moisture (\%) & $66.74^{1}$ & $45.76^{\mathrm{a}}$ & $65.48^{1}$ & $33.32^{\mathrm{b}}$ & $93.26^{2}$ & $50.95^{\mathrm{a}}$ & $187.06^{3}$ & $73.64^{c}$ \\
\hline Temperature $\left({ }^{\circ} \mathrm{C}\right)$ & 17.7 & 9.4 & 24.5 & 18.7 & 16.4 & 12.9 & 9.3 & 8.6 \\
\hline $\mathrm{pH}\left(\mathrm{H}_{2} \mathrm{O}\right)$ & $6.45^{1}$ & $6.18^{a}$ & $6.23^{2}$ & $5.86^{a}$ & $6.64^{3}$ & $5.88^{\mathrm{a}}$ & 7.294 & $5.90^{\mathrm{a}}$ \\
\hline Organic C $(\%)$ & $32.32^{1}$ & $6.06^{a}$ & $28.73^{2}$ & $5.21^{\mathrm{b}}$ & $29.41^{2}$ & $6.08^{a}$ & $30.03^{2}$ & $5.56^{\mathrm{b}}$ \\
\hline Total N $(\%)$ & $1.51^{1}$ & $0.34^{\mathrm{a}}$ & $1.54^{1}$ & $0.32^{\mathrm{a}}$ & $1.74^{2}$ & $0.36^{\mathrm{a}}$ & $1.77^{2}$ & $0.32^{\mathrm{a}}$ \\
\hline $\mathrm{C}_{\text {org }}: \mathrm{N}_{\text {total }}$ Ratio & $21.52^{1}$ & $18.05^{\mathrm{a}}$ & $18.94^{2}$ & $16.11^{\mathrm{b}}$ & $17.15^{3}$ & $16.92^{\mathrm{b}}$ & $17.30^{3}$ & $17.42^{\mathrm{a}}$ \\
\hline Available P $\left(\mu \mathrm{g} \mathrm{g}^{-1}\right)$ & $12.14^{1}$ & $4.83^{a}$ & $21.96^{2}$ & $7.64^{b}$ & $16.15^{3}$ & $5.56^{\mathrm{a}}$ & $16.31^{3}$ & $5.95^{\mathrm{a}}$ \\
\hline
\end{tabular}

Values shown by different number and lower case letter among the seasons are significantly different $(p<0.05)$.

Table 2. Seasonal changes in $\mathrm{C}_{\text {mic }}: \mathrm{C}_{\text {org }}(\%), \mathrm{C}_{\text {mic }}: \mathrm{N}_{\text {mic }}$ ratio, $\mathrm{N}_{\text {mic }}: \mathrm{N}_{\text {total }}(\%)$, and $\mathrm{C}_{\text {mic }}: \mathrm{P}_{\text {mic }}$ ratio of forest floor and soil

\begin{tabular}{|c|c|c|c|c|c|c|c|c|}
\hline \multirow{3}{*}{$\begin{array}{l}\text { Some proportions of } \\
\text { forest floor and soil }\end{array}$} & \multicolumn{8}{|c|}{ Seasons and Samples Types } \\
\hline & \multicolumn{2}{|c|}{ Spring } & \multicolumn{2}{|c|}{ Summer } & \multicolumn{2}{|c|}{ Autumn } & \multicolumn{2}{|c|}{ Winter } \\
\hline & $\begin{array}{l}\ddot{0} \\
0 \\
0 \\
4\end{array}$ & $\overline{\bar{D}}$ & 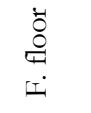 & $\overline{\bar{D}}$ & 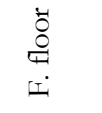 & $\overline{\bar{D}}$ & 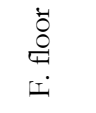 & 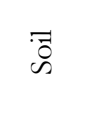 \\
\hline $\mathrm{C}_{\text {mic }}: \mathrm{C}_{\text {org }}(\%)$ & $1.45^{1}$ & $1.17^{\mathrm{a}}$ & $2.03^{2}$ & $1.65^{\mathrm{b}}$ & $1.92^{2}$ & $2.22^{\mathrm{c}}$ & $1.11^{3}$ & $1.84^{\mathrm{b}}$ \\
\hline $\mathrm{C}_{\text {mic }}: \mathrm{N}_{\text {mic }}$ Ratio & $8.10^{1}$ & $5.00^{\mathrm{a}}$ & 7.371 & $4.54^{a}$ & $6.63^{2}$ & $6.04^{b}$ & $8.48^{1}$ & $6.65^{\mathrm{b}}$ \\
\hline $\mathrm{N}_{\text {mic }}: \mathrm{N}_{\text {total }}(\%)$ & $3.83^{1}$ & $4.28^{\mathrm{a}}$ & $5.28^{2}$ & $6.10^{\mathrm{b}}$ & $5.08^{2}$ & $6.33^{\mathrm{b}}$ & $2.28^{3}$ & $5.00^{a}$ \\
\hline $\mathrm{C}_{\text {mic }}: \mathrm{P}_{\text {mic }}$ Ratio & $30.79^{1}$ & $29.02^{\mathrm{a}}$ & $27.01^{1}$ & $24.03^{\mathrm{a}}$ & $20.24^{2}$ & $24.68^{a}$ & $11.61^{3}$ & $26.25^{\mathrm{a}}$ \\
\hline
\end{tabular}

Values shown by different number and lower case letter among the seasons are significantly different $(p<0.05)$.

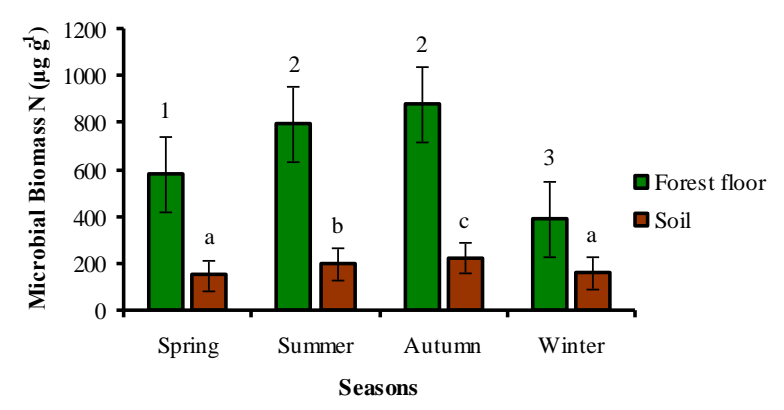

Figure 2. Seasonal changes in microbial biomass $\mathrm{N}$ content of forest floor and soil samples. Values shown by different number and lower case letter among the seasons are significantly different $(p$ $<0.05)$.

eurasscience.com
Microbial biomass $\mathbf{P}\left(\mathbf{P}_{\text {mic }}\right)$ and $\mathbf{C}_{\text {mic }}: \mathbf{P}_{\text {mic }}$

The level of microbial biomass $\mathrm{P}$ varied from 156.99 to $289.34 \mu \mathrm{g} \mathrm{g}^{-1}$ in the forest floor while in the soil the level ranged from 30.49 to $58.65 \mu \mathrm{g} \mathrm{g}^{-1}$ (Figure $3)$. The amount of forest floor microbial biomass $\mathrm{P}$ was 5 times higher than the amount of soil microbial biomass $\mathrm{P}$. The maximum value of microbial biomass $\mathrm{P}$ in the forest floor was obtained in the winter and the minimum was in the spring. The minimum value of microbial biomass $\mathrm{P}$ in soil samples was obtained in the spring, while the maximum was obtained in the autumn. Microbial biomass $\mathrm{P}$ both in the forest floor and in the soil were significantly $(p=0.000$ and 0.000 $<0.05$, respectively) different among the seasons. 


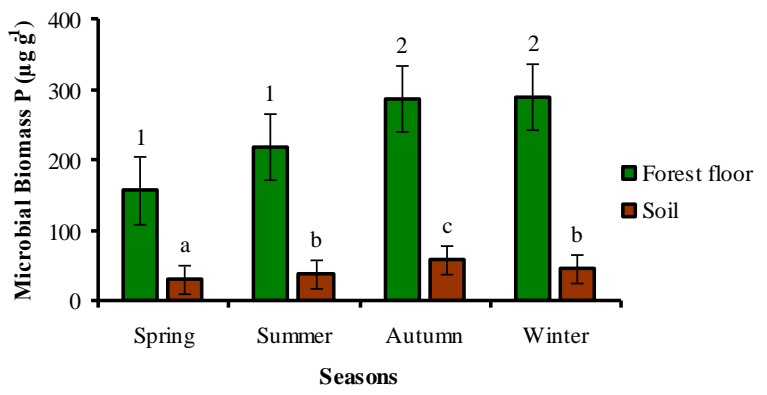

Figure 3. Seasonal changes in microbial biomass $\mathrm{P}$ content of forest floor and soil samples. Values shown by different number and lower case letter among the seasons are significantly different $(p$ $<0.05)$.

In this study, C:P ratio in microbial biomass ranged from 4.4-52.5 in the forest floor and 10.3-77.0 in the soil. Mean microbial biomass C:P ratios are shown in the Table 2. As shown in Table 2, microbial biomass C:P ratio was significantly different $(p=$ $0.000<0.05)$ among the seasons in the forest floor, but in the soil $(p=0.513>0.05)$.

\section{Basal respiration and metabolic quotient $(\mathrm{qCO})$}

Basal respiration of forest floor materials varied between 6.94 and $10.42 \mu \mathrm{g} \mathrm{CO}_{2}-\mathrm{C} \mathrm{g}^{-1}$ forest floor $\mathrm{h}^{-1}$, while basal respiration of soil varied between 0.84 and $2.06 \mu \mathrm{g} \mathrm{CO}_{2}-\mathrm{C} \mathrm{g} \mathrm{g}^{-1}$ soil h $\mathrm{h}^{-1}$ (Figure 4). Seasonally, basal respiration of the forest floor was highest during winter, whereas the highest basal respiration value of soil was found during the autumn. Minimum values were recorded during the spring both in forest floor and soil. Basal respiration of the forest floor was higher than that of soil. Basal respiration of forest floor was significantly different $(p$ $=0.000<0.05)$ among the seasons and summer, autumn and winter values were higher than spring.

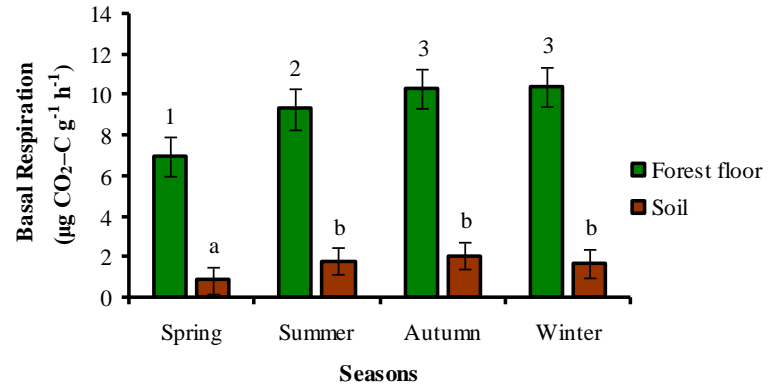

Figure 4. Seasonal changes in basal respiration of forest floor and soil samples. Values shown by different number and lower case letter among the seasons are significantly different $(p<$ 0.05).

The values of the metabolic quotient $\left(\mathrm{qCO}_{2}\right)$ ranged from 1.60 to $3.47 \mathrm{mg} \mathrm{CO}_{2}-\mathrm{C} \mathrm{g}^{-1} \mathrm{C}_{\text {mic }} \mathrm{h}^{-1}$ in the forest floor and 1.18 to $2.41 \mathrm{mg} \mathrm{CO}{ }_{2}-\mathrm{C} \mathrm{g}^{-1} \mathrm{C}_{\text {mic }} \mathrm{h}^{-1}$ in the soil (Figure 5). The highest value of $\mathrm{qCO}_{2}$ of the forest floor was obtained in winter, whereas the lowest was obtained in spring. The highest value of $\mathrm{qCO}_{2}$ of soil was found in summer and lowest was in spring. The changes in the $\mathrm{qCO}_{2}$ of forest floor and soil studied are given in Figure 5. There were no statistically significant $(p=0.348>0.05)$ difference among spring, summer and autumn for the $\mathrm{qCO}_{2}$ of forest floor. Similar results were found for the value of $\mathrm{qCO}_{2}$ of soil except summer.

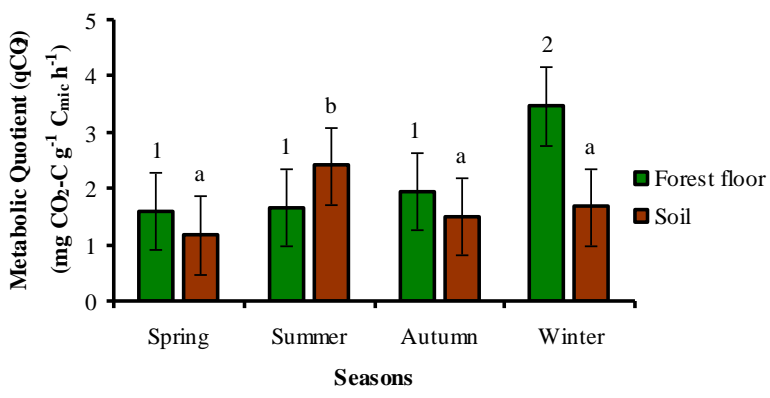

Figure 5. Seasonal changes in metabolic quotient of forest floor and soil samples. Values shown by different number and lower case letter among the seasons are significantly different $(p<0.05)$. 


\section{DISCUSSION}

\section{Biochemical properties of soil and forest floor materials}

\section{Microbial biomass $\mathrm{C} \quad\left(\mathrm{C}_{\mathrm{mic}}\right), \mathrm{C}_{\text {mic }}: \mathrm{C}_{\text {org }}$ percentage and $\mathrm{C}_{\text {mic }}: \mathrm{N}_{\text {mic }}$ ratio}

Microbial biomass $\mathrm{C}$ for forest floor values acquired in this study is similar to those in the literature. In two different studies, Chen et al. (2003; 2005) reported the microbial biomass $C$ values as $1863-9729 \mu \mathrm{g} \mathrm{g}^{-1}$ for mixed pine forest and as 978$1712 \mu \mathrm{g} \mathrm{g}^{-1}$ for mixed forest, respectively. Bauhus et al. (1998) found the microbial biomass $C$ in different soil types, age and tree species between 5570 to $13540 \mu \mathrm{g}$ $\mathrm{g}^{-1}$. Likewise, in tropical, temperate and boreal forest types this value was determined as $19-5506 \mu \mathrm{g} \mathrm{g}^{-1}$ in the forest floor (Bauhus and Khanna 1999). In this study, the obtained soil microbial biomass $\mathrm{C}$ values are similar to those indicated $\left(61-2000 \mu \mathrm{g} \mathrm{g}^{-1}\right)$ by Vance et al. (1987b) for temperate forest soil, (102$\left.2073 \mu \mathrm{g} \mathrm{g}^{-1}\right)$ by Hernot and Robertson (1994) for tropical forest soil, $\left(270-1604 \mu \mathrm{g} \mathrm{g}^{-1}\right)$ by Mahia et al. (2006) for pine forest soil, (68-1846 $\left.\mu \mathrm{g} \mathrm{g}^{-1}\right)$ by Tian et al. (2008) for mixed forest soil and (94.2-1507.8 $\mu \mathrm{g}$ g1) by Patel et al. (2010) for mixed forest soil.

Differences in the microbial biomass $\mathrm{C}$ may be due to some factors like climate conditions, soil type and properties, ground cover vegetation, number of roots, land use and management types, as well as variations in sampling times (Anderson and Domsch 1989; Priha 1999; Murrieta et al. 2007; Kara and Bolat 2008a; Kara and Bolat 2008b). For instance, there is really a positive correlation between the soil moisture with microbial biomass $\mathrm{C}(r=0.342 ; p=0.01)$ in this study. Concerning the effect of seasons on microbial biomass $\mathrm{C}$, our results differ from other presented by Diaz-Ravina et al. (1995); Alvarez et al. (2009). We found content in $\mathrm{C}$ higher in summer and autumn, in literature the highest content was seen only in winter. This difference is explained by authors as follows: high microbial biomass $\mathrm{C}$ observed in winter season could be due to a larger proportion of fungi which are the main contributors to biomass and are particularly favoured by soil humidity.

$\mathrm{C}_{\text {mic }}: \mathrm{C}_{\text {org }}$ percentage is related to substrate quality and could be used as a stability indicator for quick recognition of an environmental change
(Bauhus et al. 1998; Anderson 2003). $\mathrm{C}_{\text {mic }}: \mathrm{C}_{\text {org }}$ percentage could also serve to indicate if soil carbon is increasing, decreasing or at equilibrium (Anderson and Domsch 1989). Jenkinson and Ladd (1981) proposed that a $2.2 \mathrm{C}_{\text {mic }}: \mathrm{C}_{\text {org }}$ percentage is an equilibrium threshold for soil. A wide spectrum of $\mathrm{C}_{\text {mic }}: \mathrm{C}_{\text {org }}$ percentages varying between 0.27 and $7.0 \%$ is reported in the literature (Anderson and Domsch 1989). Bauhus and Khanna (1999) report that $\mathrm{C}_{\text {mic }}: \mathrm{C}_{\text {org }}$ percentages range from 0.3 to $8.1 \%$ in the forest floor and from 0.3 to $9.9 \%$ in soil. According to Anderson and Domsch (1989) this wide spectrum of $\mathrm{C}_{\text {mic: }}: \mathrm{C}_{\text {org }}$ percentage depends on differences in soil, vegetation cover, management, as well variations in sampling time and analytical method. $\mathrm{C}_{\text {mic }}: \mathrm{C}_{\text {org }}$ percentage values of this study (Table 2) are well within previously published ranges of $\mathrm{C}_{\text {mic }}: \mathrm{C}_{\text {org }}$.

It is reported that if $\mathrm{C}_{\text {mic }}: \mathrm{N}_{\text {mic }}$ ratio is high $(10-12)$, then the proportion of fungi in the microbial community is higher, and if it is low $\mathrm{C}_{\text {mic }}: \mathrm{N}_{\text {mic }}$ ratio (35) reflects to the predominant proportion of bacteria in the microbial biomass (Jenkinson and Ladd 1981; Joergensen et al. 1995a; Devi and Yadava 2006). A high $\mathrm{C}_{\text {mic }}: \mathrm{N}_{\text {mic }}$ ratio in our study indicates that forest floor materials have a larger proportion of fungi than bacteria in the microbial community, and for the soil vice versa. The higher values of $\mathrm{C}_{\text {mic }}: \mathrm{N}_{\text {mic }}$ ratio in winter are associated with low temperature, high moisture content and plenty of $\mathrm{N}$ in both forest floor and soil (Table 1). It is stated that there are strong correlations between the time of sampling moisture and microbial biomass (Schimel et al. 1999; Arunachalam and Arunachalam 2000) and fungi is much more adapted to low temperature conditions than bacteria (Pietikäinen et al. 2005). Results of the study fall into literature range: $\mathrm{C}_{\text {mic }}: \mathrm{N}_{\text {mic }}$ ratio of forest floor ranged from 3.0 to 17.3 (Bauhus and Khanna 1999; Chen et al. 2005), and 2.5 to 27.5 (Maithani et al. 1996; Bauhus and Khanna 1999; Merino et al. 2004; Patel et al. 2010) for forest soil.

\section{Microbial biomass $\mathbf{N} \quad\left(\mathbf{N}_{\text {mic }}\right)$ and $\mathbf{N}_{\text {mic }}: \mathbf{N}_{\text {total }}$ percentage}

The values of microbial biomass $\mathrm{N}$ obtained from the forest floor are consistent with those obtained by Bauhus et al. (1998) (663-1589 $\left.\mu \mathrm{g} \mathrm{g}^{-1}\right)$ and Bauhus and Khanna (1999) (49-1831 $\left.\mu \mathrm{g} \mathrm{g}^{-1}\right)$. However, in the forest floor of mixed forest Chen et al. (2005) found a microbial biomass $\mathrm{N}$ of 209-329 $\mu \mathrm{g} \mathrm{g}^{-1}$, which is much lower than our results. In the same study, a 
clear seasonal difference was mentioned and the highest values of microbial biomass $\mathrm{N}$ were obtained in winter and autumn during the lowest air and soil temperatures, whereas in our study the highest values were obtained only in autumn.

Although the total amount of soil microbial biomass $\mathrm{N}$ as reported by Diaz-Ravina et al. (1995) (42-191 $\left.\mu \mathrm{g} \mathrm{g}^{-1}\right)$ was found similar with the results of the study, seasonal fluctuations showed differences indicating the highest biomass $\mathrm{N}$ in the spring and winter while results of the study put forward the autumn. According to Diaz-Ravina et al. (1995) the lack of water has more influence on microbial biomass than temperature. Obviously, the soil moisture is positively correlated with microbial biomass $\mathrm{N}(r=0.275 ; p=0.01)$ in this study. Other factors are the supply of nutrients or substrate, the relative abundance of different groups of microorganisms, and other environmental variables. Patel et al. (2010) found clear annual variations in the microbial biomass $\mathrm{N}\left(23.8-128.3 \mu \mathrm{g} \mathrm{g}^{-1}\right)$ with the highest biomass $\mathrm{N}$ in rainy season and lowest biomass $\mathrm{N}$ in summer and autumn. These differences may be due to the vegetation types, moisture, temperature, $\mathrm{pH}$, mineralization and immobilization events, climatic conditions, as well as variations in sampling times in both forest floor and soil. Previous studies confirm this idea (Anderson and Domsch 1989; Priha 1999; Murrieta et al. 2007; Kara and Bolat 2008a; 2008b).

The relatively high $\mathrm{N}_{\text {mic }}: \mathrm{N}_{\text {total }}(\%)$ points out that availability of organic nitrogen components is usually unlimited for microbial biomass (Khan and Joergensen 2006). However, the low percentage of $\mathrm{N}_{\text {mic }}: \mathrm{N}_{\text {total }}$ shows a decline in substrate quality (Bauhus et al. 1998). $\mathrm{N}_{\text {mic }}: \mathrm{N}_{\text {total }}(\%)$ were all within the range of values reported by Bauhus and Khanna (1999) (0.7$19.8 \%)$ for forest floor. While $\mathrm{N}_{\text {mic }}: \mathrm{N}_{\text {total }}(\%)$ of soil is higher than those reported by Devi and Yadava (2006) (0.93-1.8\%), Diaz-Ravina et al. (1995) (1.5$4.5 \%$ ) and similar to those reported by Priha and Smolander (1997) (2.0-8.0\%), Tian et al. (2008) (1.44$12.40 \%)$, and Patel et al. (2010) (0.89-6.10\%).

\section{Microbial biomass $\mathbf{P}\left(\mathbf{P}_{\text {mic }}\right)$ and $\mathbf{C}_{\text {mic }}: \mathbf{P}_{\text {mic }}$} ratio

Seasonal changes have a significant impact on the microbial biomass $\mathrm{P}$ of forest floor and soil. The microbial biomass plays a central role in the cycling of soil phosphorus. Indeed, microorganisms are important both as a sink for phosphorus and play a role in the production of enzymes, e.g. phosphatases, hydrolases, that catalyse the mineralization of organicP (Jenkinson and Ladd 1981; Stewart and Tiessen 1987; Hughes and Reynolds 1991). Also, microbes compete aggressively with plants for available $\mathrm{P}$ in soil. The importance of microbial immobilization of $\mathrm{P}$ is illustrated by the fact that microbes often contain as much as $20-30 \%$ of the total soil organic $\mathrm{P}$, which is much larger than the proportion of $\mathrm{C}(\sim 1-2 \%)$ or $\mathrm{N}$ $(\sim 2-10 \%)$ held in microbes. However, the capacity of the soil microbial biomass to act as a sink for $\mathrm{P}$ is strongly affected by environmental stresses, such as wetting and drying, which are known to result in the death of a portion of the soil microbial biomass. Microbial biomass $\mathrm{P}$ is, therefore, an important source of potentially available $\mathrm{P}$ in soil (Bardgett 2005). According to Hedley et al. (1982) microorganisms growing in media with a high $\mathrm{P}$ content usually assimilate more $\mathrm{P}$ than those growing in media with low P content.

The values obtained for microbial biomass $\mathrm{P}$ of the forest floor in this study were more or less consistent with the order of the range reported by Bauhus and Khanna (1999) (95-328 $\mu \mathrm{g} \mathrm{g}^{-1}$ ) and by

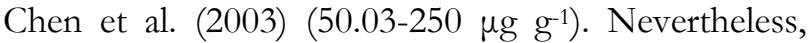
the level of microbial biomass $\mathrm{P}$ in the forest floor exceeded the values reported by Hughes and Reynolds (1991) (95.0-168.0 $\left.\mathrm{gg} \mathrm{g}^{-1}\right)$, while it remained below the values reported by Chen et al. (2000) (38$\left.503 \mu \mathrm{g} \mathrm{g}^{-1}\right)$. In the present study, microbial biomass $\mathrm{P}$ of soil is well within previous literature. For example, it has been reported that microbial biomass $\mathrm{P}$ of soil varied between 1.5-50 $\mu \mathrm{g} \mathrm{g}^{-1}$ (Hedley and Stewart 1982) with 5-75 $\mu \mathrm{g} \mathrm{g}^{-1}$ (Plante 2007). On the other hand, microbial biomass $\mathrm{P}$ of soil was $67.2 \mu \mathrm{g} \mathrm{g} \mathrm{g}^{-1}$ (Brookes et al. 1984) for deciduous forest, 9.23-74.81 $\mu \mathrm{g} \mathrm{g} \mathrm{g}^{-1}$ (Arunachalam and Arunachalam 2000) for subtropical humid forest, 17.7-174.3 $\mu \mathrm{g} \mathrm{g}^{-1}$ : mean $60.6 \mu \mathrm{g} \mathrm{g}^{-1}$ (Joergensen et al., 1995b) for Fagus sylvatica forest. These differences in the microbial biomass $\mathrm{P}$ may be due to the vegetation types, moisture, temperature, $\mathrm{pH}$, mineralization and immobilization events, climatic conditions, as well as variations in sampling times in both forest floor and soil (DiazRavina et al. 1995; Devi and Yadava 2006; Alvarez et al. 2009; Patel et al. 2010).

Tate et al. (1991) and He et al. (1997) noted that there is a relation between levels of plant available $\mathrm{P}$ and microbial biomass C:P ratio. Low 
microbial biomass C:P ratio indicated high potential P release from biomass, while high microbial biomass C:P ratios illustrated the potential P immobilization in biomass. Although Bauhus and Khanna (1999) found the microbial biomass C:P ratio (13.3-36.5) to be lower than results of the study, the results of Chen et al. (2003) were found to be higher (22-219) than present study. The differences of the results can be explained by different vegetation type, quality of forest floor, macroclimate, and stand canopy. The literature indicates that there is a relationship between biomass C:P ratio and stand canopy, which the significant increase in biomass C:P ratio in the understory is due to relatively sharper increase in microbial $\mathrm{C}$ beneath closed canopy (Arunachalam and Arunachalam 2000). Although microbial biomass C:P ratio in the soil was similar to the ranges reported in some studies, Bauhus and Khanna (1999) (5.1-35.1), Chen et al. (2003) (19-65) and Devi and Yadava (2006) (14.90-26.70) have found this ratio higher than present results. This can be explained by low microbial biomass $\mathrm{P}$ and high microbial biomass $\mathrm{C}$ levels (Khan and Joergensen 2006).

\section{Basal respiration and metabolic quotient $(\mathrm{qCO})$}

Basal respiration (soil respiration), which is the oxidation of organic matter to $\mathrm{CO}_{2}$ by aerobic microorganism, correlates significantly with soil organic matter and most microbial parameters and is a key process in the carbon cycle of terrestrial ecosystems (Alef 1995; Winding et al. 2005). Soil basal respiration also provides an estimate of microbial activity. Different microbial activities reflect differences in the cycling of the organic carbon and organic carbon-bound nutrients within an ecosystem, such as carbon, nitrogen, sulfur and phosphorus (Winding et al. 2005). Chen et al. (2003) found that basal respiration of soil (forest and grassland soils) and forest floor materials was $0.17-0.65 ; 0.11-0.84 \mu \mathrm{g}$ $\mathrm{CO}_{2}-\mathrm{C} \mathrm{g}^{-1}$ soil h$^{-1}$ and 1.21-40.94; 1.71-14.24 $\mu \mathrm{g} \mathrm{CO}_{2^{-}}$ $\mathrm{C} \mathrm{g}^{-1}$ forest floor $\mathrm{h}^{-1}$, respectively. They also found that basal respiration increased in the late spring season but decreased in the autumn and winter. In addition, basal respiration values of soil obtained in this study coincide with those reported by Alvarez et al. (2009) (0.30-1.20 $\mu \mathrm{g} \mathrm{CO}_{2}-\mathrm{C} \mathrm{g}^{-1}$ soil h$\left.{ }^{-1}\right)$, Tian et al. (2008) (0.49-1.94 $\mu \mathrm{g} \mathrm{CO}_{2}-\mathrm{C} \mathrm{g}^{-1}$ soil h$\left.^{-1}\right)$ and Merino et al. (2004) (0.65-1.05 $\mu \mathrm{g} \mathrm{CO}_{2}-\mathrm{C} \mathrm{g}^{-1}$ soil $\left.\mathrm{h}^{-1}\right)$. Basal respiration values of forest floor and soil in the present study were higher in summer and autumn because of the high soil temperature and moisture (Table 1), which might promote the microbial activity. Hence, soil basal respiration is positively correlated with microbial biomass $C(r=0.715 ; p=0.01)$ and microbial biomass $\mathrm{N}(r=0.665 ; p=0.01)$ in this study. According to Sparling (1997) and Alvarez et al. (2009) soil respiration is a well-established parameter to monitor decomposition, but it is also highly variable and can show wide natural fluctuation depending on substrate availability, moisture and temperature.

Odum (1985) and Anderson and Domsch (1993) asserted that high $\mathrm{qCO}_{2}$ can be a sign of a stress response. Inversely, decreases in $\mathrm{qCO}_{2}$ have been related to plant succession (Insam and Haselwandter 1989). $\mathrm{qCO}_{2}$ gives an integrated measure of the ecophysiological state of the soil microbial community (Anderson and Domsch 1985; Insam et al. 1996) as well as on the substrate quality and availability (Dilly et al. 1997; Dilly and Munch 1998). Anderson (2003) reported that metabolic quotient $\left(\mathrm{qCO}_{2}\right)$ varied between 0.5 and $2.0 \mathrm{mg} \mathrm{CO}_{2^{-}}$ $\mathrm{C} \mathrm{g}^{-1} \mathrm{C}_{\text {mic }} \mathrm{h}^{-1}$ in neutral soil. In our study, $\mathrm{qCO}_{2}$ of forest floor and soil are above $2.0 \mathrm{mg} \mathrm{CO} \mathrm{CO}_{2}-\mathrm{C} \mathrm{g}^{-1} \mathrm{C}_{\text {mic }}$ $\mathrm{h}^{-1}$ in winter and summer, respectively (Figure 5). This could be explained by low temperature and high moisture in winter, which slows down the decomposition of forest floor. Therefore, the $\mathrm{qCO}_{2}$ of soil is negatively correlated with soil moisture $(r=$ $0.171 ; p>0.05)$ and microbial biomass $\mathrm{C}(r=-0.266$; $p=0.01)$ in this study. Also, $\mathrm{qCO}_{2}$ of forest floor and soil may be influenced by the amount and quality of organic C used for basal respiration because basal respiration is positively correlated with soil organic $\mathrm{C}$ and microbial biomass, and the availability of suitable substrates (protein, carbohydrate, glucose, etc.). Hereby, due to the fact that the organic $\mathrm{C}$ content of soil samples is lower in summer than in other seasons (Table 1), $\mathrm{qCO}_{2}$ of soil could have been higher in summer. Anderson and Domsch (1986); Bauhus and Khanna (1999) reported similar findings; they indicated that if $\mathrm{qCO}_{2}$ is high, available $\mathrm{C}$ content and substrate quality are low for microbial biomass. Therefore, little biomass can be produced because more carbon is used for respiration (Anderson 2003). The present values of soil $\mathrm{qCO}_{2}$ fall within the informed range of subtropical forest (0.74-10.17; Tian et al. 2008), temperate deciduous forest (0.75-1.62; Alvarez et al. 2009), conifer forest (1.8-2.6; Merino et al. 2004). 


\section{CONCLUSIONS}

Seasonal changes in environmental conditions such as temperature and moisture facilitate the turnover of microbial biomass and consequently can perform an important role in controlling nutrient availability. Results obtained in this study clearly demonstrated that the amount of $\mathrm{C}, \mathrm{N}, \mathrm{P}$, microbial biomass and basal respiration observed in forest floor and soil are different and generally higher in the forest floor. Our results also showed that in both forest floor and soil microbial biomass C, N, P and basal respiration change in accordance with soil moisture, soil temperature, organic matter content and structure of microbial community. For instance, the soil moisture is positively correlated with microbial biomass $\mathrm{C}$ and microbial biomass $\mathrm{N}$ while the soil basal respiration is positively correlated with microbial biomass $\mathrm{C}$ and microbial biomass $\mathrm{N}$ in this study. Additionally, the $\mathrm{qCO}_{2}$ of soil is negatively correlated with soil moisture and microbial biomass $\mathrm{C}$ in this study. Particularly, the variation in the microbial biomass $\mathrm{C}, \mathrm{N}, \mathrm{P}$ and basal respiration as well as $\mathrm{C}_{\text {org }}$, $\mathrm{C}_{\text {mic }}$ : $\mathrm{C}_{\text {org }}(\%)$ and $\mathrm{N}_{\text {mic }}: \mathrm{N}_{\text {total }}(\%)$ correspond to seasonal changes. In other words, higher microbial biomass and basal respiration have usually been observed in summer and autumn while lower values in spring and winter. Because microbial biomass is used as indicator of soil activity, our findings suggest that under the very humid and mesothermal climate of the Western Black Sea region of Turkey, soil may be more active in summer and autumn than in spring and winter. Also, the data of the study can be utilized comparatively for monitoring the possible future changes in the microbial biomass and basal respiration of forest floor and soil under Bornmullerian fir stand.

\section{ACKNOWLEDGMENTS}

The authors gratefully acknowledge the English advice and support of William H. DcDowell, Professor of Environmental Science and Presidential Chair, Department of Natural Resources and Environment, University of New Hampshire. Additionally, the authors would like to thank the anonymous referees for their comments and constructive suggestions. We would also like to thank the associate editor for reviewing various versions of this manuscript. Finally, the authors have declared no conflict of interest with any other persons or communities.

\section{References}

Alef, K. (1995). Soil respiration. In: K. Alef, P. Nannipieri (eds). Methods in Applied Soil Microbiology and Biochemistry. London, San Diego, CA, USA: Academic Press pp: 214-219.

Alvarez, E., Torrado, V.M., Fernandez Marcos M.L. and Diaz-Ravia, M. (2009). Microbial biomass and activity in a forest soil under different tree species. Electronic Journal of Environmental, Agricultural and Food Chemistry 8 (9): 878-887

Anderson, J. M. and Ingram, J. S. I. (1996). Tropical Soil Biology and Fertility A Handbook of Methods, $2^{\text {nd }}$ edn. Wallingford, UK: Cab International, $221 \mathrm{p}$.

Anderson, J. P. E. and Domsch, K. H. (1989). Ratios of microbial biomass carbon to total organic carbon in arable soils. Soil Biology and Biochemistry 21: 471-479

Anderson, T. H. (2003). Microbial eco-physiological indicators to assess soil quality. Agriculture Ecosystems and Environment 98: 285-293

Anderson, T. H. and Domsch, K. H. (1985). Maintenance requirements of actively metabolizing microbial populations under in situ conditions. Soil Biology and Biochemistry 17: 197-203

Anderson, T. H. and Domsch, K. H. (1986). Carbon link between microbial biomass and soil organic matter. In: F.Megusar, M. Gantar (eds). Perspectives in Microbial Ecology. Slovene Society for Microbiology, Ljubljana, Mladinska knjiga, pp: 467-471

Anderson, T. H. and Domsch, K. H. (1990). Application of eco-physiological quotients $\left(\mathrm{qCO}_{2}\right.$, and $\left.\mathrm{qD}\right)$ on microbial biomasses from soils of different cropping histories. Soil Biology and Biochemistry 22: 251-255

Anderson, T. H. and Domsch, K. H. (1993). The metabolic quotient for $\mathrm{CO}_{2}\left(\mathrm{qCO}_{2}\right)$ as a specific activity parameter to assess the effects of environmental conditions, such as $\mathrm{pH}$, on the microbial biomass of forest soils. . Soil Biology and Biochemistry 25: 393-395

Arunachalam, A. and Arunachalam, K. (2000). Influence of gap size and soil properties on microbial biomass in a subtropical humid forest of northeast India. Plant and Soil 223: 185-193

Bardgett, R. D. (2005). The Biology of Soil: A Community and Ecosystem Approach. $1^{\text {st }}$ edn. Oxford, UK: Oxford University Press, 242 p. 
Bauhus, J. and Khanna, P. K. (1999). The significance of microbial biomass in forest soils. In: N. Rastin, J. Bauhus (eds). Going underground-ecological studies in forest soils. Trivandrum, India: Research Signpost, pp: 77-110

Bauhus, J. D., Pare, D. and Cote, L. (1998). Effects of tree species, stand age, and soil type on soil microbial biomass and its activity in a southern boreal forest. Soil Biology and Biochemistry 30: 1077-1089

Brookes, P.C., Landman, A., Pruden, G. and Jenkinson, D. S. (1985). Chloroform fumigation and the release of soil nitrogen: A rapid extraction method to measure microbial biomass nitrogen in soil. Soil Biology and Biochemistry 17: 837-842

Brookes, P. C., Powlson, D. S. and Jenkinson, D. S. (1982). Measurement of microbial biomass phosphorus in soil. Soil Biology and Biochemistry 14: 319-329

Brookes, P. C., Powlson, D. S. and Jenkinson, D. S. (1984). Phosphorus in the soil microbial biomass. Soil Biology and Biochemistry 16: 169-175

Bouyoucos, G. J. (1962). Hydrometer method improved for making particle size analyses of soils, Agronomy Journal 54: 464-465

Chen, C. R., Condron, L. M., Davis, M. R. and Sherlock, R. R. (2000). Effects of afforestation on phosphorus dynamics and biological properties in a New Zealand grassland soil. Plant and Soil 220: 151-163

Chen, C. R., Condron, L. M., Davis, M. R. and Sherlock, R. R. (2003). Seasonal changes in soil phosphorus and associated microbial properties under adjacent grassland and forest in New Zealand. Forest Ecology and Management 177: 539-557

Chen, T. H., Chiu, C. Y. and Tian, G. L. (2005). Seasonal dynamics of soil microbial biomass in coastal sand dune forest. Pedobiologia 49: 645-653

Devi, N. B. and Yadava, P. S. (2006). Seasonal dynamics in soil microbial biomass $\mathrm{C}, \mathrm{N}$ and $\mathrm{P}$ in a mixed-oak forest ecosystem of Manipur, Northeast India. Applied Soil Ecology 31: 220-227

Diaz-Ravina, M., Acea, M. J. and Carballas, T. (1995). Seasonal changes in microbial biomass and nutrient flush in forest soils. Biology and Fertility of Soils 19: 220226

Dilly, O. and Munch, J. C. (1998). Ratios between estimates of microbial biomass content and microbial activity in soils. Biology and Fertility of Soils 27: 374-379

Dilly, O., Bernhard. M., Kutsch, W. L., Kappen, L. and Munch, J. C. (1997). Aspects of carbon and nitrogen cycling in soils of the Bornhoved Lake district I. Microbial characteristics and emission of carbon dioxide and nitrous oxide of arable and grassland soils. Biogeochemistry 39: 189-205

Dinesh, R., Srinivasan, V., Hamza, S., Manjusha, A. and Kumar, P. S. (2012). Short-term effects of nutrient management regimes on biochemical and microbial properties in soils under rainfed ginger (Zingiber officinale Rosc.). Geoderma 173-174:192-198

Gülçur, F. (1974). Soil Physical and Chemical Analysis Methods (In Turkish). İstanbul University Publication No. 1970, Forest Faculty Publication No. 201, İstanbul, Turkey: Kutulmuş Printing, 225 p.

He, Z. L., Wu, J., O’Donnell, A. G. and Syers, J. K. (1997). Seasonal responses in microbial biomass carbon, phosphorus and sulphur in soils under pasture. Biology and Fertility of Soils 24: 421-428

Hedley, M. J. and Stewart, J. W. B. (1982). Method to measure microbial biomass phosphate in soils. Soil Biology and Biochemistry 14: 377-385

Hedley, M. J., White, R. E. and Nye, P. H. (1982). Plantinduced changes in the rhizosphere of rape (Brassica napus var. emerald) seedlings. III. Changes in L value, soil phosphate fractions and phosphatase activity. New Phytologist 91: 45-56

Hernot, J. and Robertson, G. P. (1994). Vegetation removal in two soils of the humid tropics: effect on microbial biomass. Soil Biology and Biochemistry 26: 111-116

Hughes, S. and Reynolds, B. (1991). Effects of clear felling on microbial biomass phosphorus in the Oh horizon of an afforested podzol in Mid-Wales. Soil Use Management 7: 183-188

Insam, H. and Haselwandter, K. (1989). Metabolic quotient of the soil microflora in relation to plant succession. Oecologia 79: 174-178

Insam, H., Hutchinson, T. C. and Reber, H. H. (1996). Effects of heavy metal stress on the metabolic quotient of soil microflora. Soil Biology and Biochemistry 28: 691-694

Jenkinson, D. S. and Ladd, J. N. (1981). Microbial biomass in soil measurement and turnover. In: E. A. Paul, J. N. Ladd (eds). Soil biochemistry. Volume 5, New York and Basel, USA: Marcel Dekker Inc, pp: 415-471

Joergensen, R. G., Anderson, T. H. and Wolters, V. (1995a). Carbon and nitrogen relationships in the microbial biomass of soils in beech (Fagus sylvatica L.) forests. Biology and Fertility of Soils 19: 141-147

Joergensen, R. G., Kübler, H., Meyer. B. and Wolters, V. (1995b). Microbial biomass phosphorus in soils of beech (Fagus sylvatica L.) forests. Biology and Fertility of Soils 19: 215-219 
Kacar, B. (1996). Plant and Soil Chemical Analysis, III. Soil Analysis (In Turkish). Ankara University, Faculty of Agriculture, Education, Research and Development Foundation Publications, No: 3, Ankara, Turkey, 705 p.

Kara, Ö. and Bolat, İ. (2008a). Soil microbial biomass C and $\mathrm{N}$ changes in relation to forest conversion in the northwestern Turkey. Land Degradation and Development 19 (4): 421-428

Kara, Ö. and Bolat, İ. (2008b). The effect of different land uses on soil microbial biomass carbon and nitrogen in Bartın province. Turkish Journal of Agriculture and Forestry 32 (4): 281-288

Kara, Ö., Bolat, İ., Çakıroğlu, K. and Öztürk, M. (2008). Plant canopy effects on litter accumulation and soil microbial biomass in two temperate forests. Biology and Fertility of Soils 45 (2): 193-198

Kara, Ö., Bolat, İ., Çakıroğlu, K. and Şentürk, M. (2014). Litter decomposition and microbial biomass in temperate forests in Northwestern Turkey. Journal of Soil Science and Plant Nutrition 14 (1): 31-41

Karaöz, M. Ö. (1992). Leaf and litter analiysis methods (In Turkish). Journal of the Faculty of Forestry, Istanbul University, Series B 42 (1-2): 57-71

Khan, K. S. and Joergensen, R. G. (2006). Microbial C, N and $\mathrm{P}$ relationships in moisture stressed soils of Potohar, Pakistan. Journal of Plant Nutrition and Soil Science 169: 494-500

Kramer, S. and Green, D. M. (2000). Acid and alkaline phosphatase dynamics and their relationship to soil microclimate in a semiarid woodland. Soil Biology and Biochemistry 32: 179-188

Mahia. J., Perez Ventura, L., Cabaneiro, A. and DiazRavina, M. (2006). Soil microbial biomass under pine forest in the northwestern Spain: influence of stand age, site index and parent material. Investigaciones Agrarias: Sistemas y Recursos Forestales 15 (2): 152-159

Maithani, K., Tripathi. R. S., Arunachalam, A. and Pandey, H. N. (1996). Seasonal dynamics of microbial biomass $\mathrm{C}, \mathrm{N}$ and $\mathrm{P}$ during regrowth of a disturbed subtropical humid forest in northeast India. Applied Soil Ecology 4: 31-37

Merino, A., Fernandez-Lopez, A., Solla-Gullon, F. and Edeso, J. M. (2004). Soil changes and tree growth in intensively managed Pinus radiata in northern Spain. Forest Ecology and Management 196: 393-404

Murrieta, V. M. S., Govaerts, B. and Dendooven, L. (2007). Microbial biomass $C$ measurements in soil of the central highlands of Mexico. Applied Soil Ecology 35: 432-440

eurasscience.com
Nielsen, M. N. and Winding, A. (2002). Microorganisms as Indicators of Soil Health. National Environmental Research Institute, Technical Report No. 388, Denmark 1-84.

Odum, E. P. 1985. Trends expected in stressed ecosystems. Bioscience 35: 419-422

Olsen, S. R., Cole, C. V., Watanabe, F. S. and Dean, L. A. (1954). Estimation of available phosphorus in soils by extraction with sodium bicarbonate. Circular 939, United States Department of Agriculture, Washington DC.

Pankhurst, C. E., Doube, B. M. and Gupta, V. V. S. R. (1997). Biological indicators of soil health: synthesis. In: C. E. Pankhurst, B. M. Doube, V. V. S. R Gupta (eds). Biological Indicators of Soil Health, Wallingford, UK: CAB International, pp: 419-435

Patel, K., Nirmal Kumar, J. I. N., Kumar, R. and Kumar Bhoi, R. (2010). Seasonal and temporal variation in soil microbial biomass $\mathrm{C}, \mathrm{N}$ and $\mathrm{P}$ in different types land uses of dry deciduous forest ecosystem of Udaipur, Rajasthan, Western India. Applied Ecology and Environmental Research 8 (4): 377-390

Pietikäinen, J., Pettersson, M. and Bååth, E. (2005). Comparison of temperature effects on soil respiration and bacterial and fungal growth rates. FEMS Microbiology Ecology 52: 49-58

Plante, A. F. (2007). Soil biogeochemical cycling of inorganic nutrients and metals. In: E. A. Paul (ed). Soil microbiology, ecology and biochemistry, Canada: Academic press, pp: 389-430.

Powlson, D. S. and Jenkinson, D. S. (1981). A comparison of the organic-matter, biomass, adenosinetriphosphate and mineralizable nitrogen contents of ploughed and direct-drilled soils. Journal of Agricultural Science 97: 713-721

Powlson, D. S., Brookes, P. C. and Christensen, B. T. (1987). Measurement of microbial biomass provides an early indication of changes in total soil organic matter due to the straw incorporation. Soil Biology and Biochemistry 19: 159-164

Priha, O. (1999). Microbial activities in soils under Scots pine, Norway spruce and Silver birch. Research Papers 731, Finnish Forest Research Institute, Helsinki.

Priha, O. and Smolander, A. (1997). Microbial biomass and activity in soil and litter beneath Pinus sylvestris, Picea abies and Betula pendula at originally similar field afforestation sites. Biology and Fertility of Soils 24: 45-51

Rowell, D. L. (1994). Soil Science: Methods and Applications. $1^{\text {st }}$ edn. Longman Group Ltd. London, UK: Prentice Hall, 350 p. 
Schimel, J. P., Gulledge, J. M., Clein-Curley, J. S., Lindstrom, J. E. and Braddock, J. F. (1999). Moisture effects on microbial activity and community structure in decomposing birch litter in the Alaskan taiga. Soil Biology and Biochemistry 31: 831-838

Sparling, G. P. (1997). Soil microbial biomass, activity and nutrient cycling as indicators of soil health. In: C. E. Pankhurst, B. M Doube, V. V. S. R. Gupta (eds). Biological Indicators of Soil Health, Wallingford, UK: CAB International, pp: 97-119

Stewart, J. W. B. and Tiessen, H. (1987). Dynamics of soil organic phosphorus. Biogeochemistry 4: 41-60

Tate, K. R., Speir, T. W., Ross, D. J., Parfitt, R. L., Whale, K. N. and Cowling, J. C. (1991). Temporal variations in some plant and soil $\mathrm{P}$ pools in two pasture soils of widely different P fertility status. Plant and Soil 132: 219-232

TGDF (Turkish General Directorate of Forestry) (2001) Forest management plans of Arit forest administration. Ankara, Turkey.

Tian, Y., Haibara, K., Toda, H., Ding, F., Liu, Y. and Choi. D. (2008). Microbial biomass and activity along a natural $\mathrm{pH}$ gradient in forest soils in a karst region of the upper Yangtze River, China. Journal of Forest Research-Jpn 13: 205-214

Vance, E. D., Brookes, P. C. and Jenkinson, D. S. (1987a). An extraction method for measuring soil microbial biomass C. Soil Biology and Biochemistry 19: 703-707

Vance, E. D., Brookes, P. C. and Jenkinson, D. S. (1987b). Microbial biomass measurements in forest soils: the use of chloroform fumigation-incubations methods for strongly acid soils. Soil Biology and Biochemistry 19: 697-702

Winding, A., Hund-Rinke, K. and Rutgers, M. (2005). The use of microorganisms in ecological soil classification and assessment concepts. Ectoxicology and Enviromental Safety 62: 230-248

Submitted: 21.01.2015

Accepted: 09.04.2015 